\title{
The Impact of Coaching, Experience and Technical Post on Precompetitive Anxiety among Elite U15 Footballers Affiliated to the Sectorial Training Centers of the Tunisian Football Federation (TFF)
}

\author{
Jamel Hajji1,2, Ali Elloumi ${ }^{3,4}$ \\ ${ }^{1}$ Department of Sciences Education, Faculty of Humanities at Tunis, University of Tunis, Tunis, Tunisia \\ ${ }^{2}$ Higher Institute of Sport and Physical Education Gafsa, Gafsa University, Gafsa, Tunisia \\ ${ }^{3}$ Department of Arts and Sciences Social, Sfax University, Sfax, Tunisia \\ ${ }^{4}$ Laboratoire Techniques et Enjeux du Corps, Universite Paris Descartes, Paris, France \\ Email: Hajji5jamel@yahoo.fr
}

How to cite this paper: Hajji, J., \& Elloumi, A. (2018). The Impact of Coaching, Experience and Technical Post on Precompetitive Anxiety among Elite U15 Footballers Affiliated to the Sectorial Training Centers of the Tunisian Football Federation (TFF). Advances in Physical Education, 8, 157-171.

https://doi.org/10.4236/ape.2018.82015

Received: January 28, 2018

Accepted: April 5, 2018

Published: April 8, 2018

Copyright $\odot 2018$ by authors and Scientific Research Publishing Inc. This work is licensed under the Creative Commons Attribution International License (CC BY 4.0).

http://creativecommons.org/licenses/by/4.0/

\begin{abstract}
Precompetitive anxiety is a psychological constraint for young athletes in an institutional system characterized by a selective environment such as training centers. The objective of our study is to examine cognitive anxiety, somatic and precompetitive self-confidence through measures, intensity, direction and frequency, among $76 \mathrm{U} 15$ elite footballers affiliated in the sectorial training centers. Supervised by the Tunisian Football Federation, the data were collected and analyzed by version 22.0.0. IBM SPSS and AMOS. In our young footballers with neglected psychological framework, the results show that self-confidence through its three measures represents the most identified dimension among our participants. On the other hand, the analysis of MANOVA demonstrated only the effect of coaching on the strategies of mental imagery, control of thoughts, deployment of effort and relaxation. Identifying the manifestation of precompetitive anxiety is an essential step in effectively managing the stressful situation.
\end{abstract}

\section{Keywords}

Cognitive Anxiety, Somatic Anxiety, Self-Confidence, Training Centers, Experience Level, Coaching, Player's Technical Position

\section{Introduction}

Over the course of half a century, anxiety has been frequently considered in 
sports psychology as an acting emotion on performance (Grossbard et al., 2009: pp. 153-166).

Consequently, concern about anxiety as a negative emotion (Lazarus, 2000: pp. 229-252), has been addressed in many ways such as its nature and role in the field of sport (Woodman \& Hardy, 2003: pp. 443-457).

In this context, several unidimensional and multidimensional theoretical models have appreciated competitive anxiety. The transactional model of Lazarus and Folkman (1984), is one of the most important models that has been agreed upon. This model indicates that the well-being of the athlete is endangered when the anticipation of the situation is threatening, and the achievement of the objective and the performance are put in a critical situation.

Anxiety that derives from the individual's uncertain confrontation with environmental aggression is indicated as an unpleasant emotion (Lazarus, 2000: pp. 229-252; Skinner \& Brewer, 2002: pp. 678-692).

Some researchers in the field of sport psychology confirm that an unfavorable performance may be a result of a high level of competitive situational anxiety (Hardy, 1999: pp. 227-233; Horikawa \& Yagi, 2012: pp. 1-5).

The evaluation of precompetitive anxiety among our youth participants will provide us with a thorough understanding of the threatening situation, its interpretation and its frequency over time, with respect to coaching factors, level of experience and technical position, considered as environmental constraints in the training of young footballers.

The works of Khodayari et al. (2011: pp. 2280-2284), Sangari et al. (2012: pp. 1175-1178), indicate that the level of competitive anxiety can be modified. However, the development of mental methods and techniques is essential, in order to reduce competitive anxiety and improve performance.

\section{Population}

These are 76 Tunisian U15 footballers (average age 14.00, ET: 0.327), affiliated to the sectorial pre-training centers. These young athletes are subject to a training program supervised by the Tunisian National Technical Direction (Table $1)$.

\section{Measure}

To evaluate pre-competitive situational anxiety, we used the Tunisian version of the Competitive State Anxiety Inventory-2 Revised (CSAI-2R) including frequency and direction scales (Hajji \& Elloumi, 2017: pp. 1-7).

This version has allowed us to measure the level of intensity, direction and frequency of cognitive pre-competitive anxiety, somatic and the level of confidence a few minutes of the competition.

The intensity scale designed to measure precompetitive anxiety scores, each item is estimated on a four-point Likert scale $(1=$ not at all, $2=$ somewhat, $3=$ moderately, $4=$ all at fact). 
Table 1. The population of the study.

\begin{tabular}{cccc}
\hline & & Numbers & $\%$ \\
\hline \multirow{3}{*}{ Training } & Gafsa & 20 & 26.3 \\
Center & Sidi Bouzid & 19 & 25.0 \\
& Gabes & 20 & 26.3 \\
Experience Level & Kef & 17 & 22.4 \\
& Below 2 years & 26 & 34.2 \\
Technical Position & Over 2 years & 50 & 65.8 \\
Player & Goalkeeper & 10 & 13.2 \\
& Defender player & 22 & 28.9 \\
& Midfield player & 21 & 27.6 \\
& Attacking player & 23 & 30.3 \\
\hline
\end{tabular}

The direction scale designed to evaluate the directional interpretation of precompetitive anxiety. Responses range from minus three $(-3)$ to plus three $(+3)$ $(-3=$ very unfavorable, $-2=$ somewhat unfavorable, $-1=$ somewhat unfavorable, $0=$ no effect on performance, $+1=$ somewhat favorable, $+2=$ quite favorable, +3 very favorable).

The frequency scale designed to evaluate the spread of pre-competitive anxiety over time, in this scale the responses range from 1 point (not at all) to 7 points (all the time).

\section{Procedure}

After informing the managers of each training center through letters of recommendation certified by the National Technical Department, and after obtaining the consent of the coaches and parents, the athletes were invited during their sectorial groupings, to settle against the Tunisian version of CSAI-2R, $30 \mathrm{mi}$ nutes before the competition.

In this context, studies by Stavrou et al. (2006: pp. 91-98), indicate that the level of intensity and direction of precompetitive anxiety varies from one day to 30 minutes before the competition.

\section{Result}

\subsection{The Psychometric Properties of the Tunisian Version of CSAI-2R}

\subsubsection{The Internal Consistency of the Tunisian Version CSAI-2R}

The Cronbach alpha coefficients of our measurement instrument of the Tunisian version of CSAI-2R (Hajji \& Elloumi, 2017), and the French version (Martinent et al., 2010), are shown in Table 2.

\subsubsection{Exploratory Factor Analysis}

The indices of the exploratory factor analysis are shown in Table 3. 
Table 2. Cronbach alpha coefficients.

\begin{tabular}{|c|c|c|c|c|c|}
\hline & CSAI-2R & $\begin{array}{c}\text { Alpha } \\
\text { Cronbach }\end{array}$ & $\mathrm{N}$ & $\begin{array}{l}\text { Alpha Cronbach from } \\
\text { The Tunisian Version } \\
\text { (Hajji \& Elloumi, 2017) }\end{array}$ & $\begin{array}{l}\text { Alpha Cronbach of } \\
\text { The French Version } \\
\text { (Martinent et al, 2010) }\end{array}$ \\
\hline \multirow{4}{*}{ Intensity } & Cognitive anxiety & 0.774 & 5 & 0.82 & 0.80 \\
\hline & Somatic anxiety & 0.912 & 6 & 0.87 & 0.77 \\
\hline & Self-confidence & 0.891 & 5 & 0.87 & 0.83 \\
\hline & Scale of intensity & 0.734 & 16 & -- & -- \\
\hline \multirow{4}{*}{ Direction } & Cognitive anxiety & 0.856 & 5 & 0.87 & 0.81 \\
\hline & Somatic anxiety & 0.891 & 6 & 0.90 & 0.82 \\
\hline & Self-confidence & 0.836 & 5 & 0.87 & 0.76 \\
\hline & Scale of direction & 0.875 & 16 & -- & -- \\
\hline \multirow{4}{*}{ Frequency } & Cognitive anxiety & 0.828 & 5 & 0.76 & 0.77 \\
\hline & Somatic anxiety & 0.908 & 6 & 0.80 & 0.77 \\
\hline & Self-confidence & 0.802 & 5 & 0.87 & 0.78 \\
\hline & Scale of frequency & 0.768 & 16 & -- & -- \\
\hline
\end{tabular}

Table 3. The indices of the exploratory analysis.

\begin{tabular}{|c|c|c|c|}
\hline & Scale of intensity & Scale of direction & Scale of frequency \\
\hline Determinant & $4.149 \mathrm{E}-5$ & $7.118 \mathrm{E}-5$ & $5.701 \mathrm{E}-5$ \\
\hline KMO Index & 0.801 & 0.839 & 0.806 \\
\hline Chi-square & 694.528 & 657.380 & 672.660 \\
\hline \multirow[t]{2}{*}{$\begin{array}{l}\text { Sphericity test } \\
\text { from Bartlett }\end{array}$} & 120 & 120 & 120 \\
\hline & 0.000 & 0.000 & 0.000 \\
\hline
\end{tabular}

The factor loads of the three scales are shown in Table 4.

\subsubsection{Confirmatory Factors Analysis}

The adjustment indices for the three subscales are shown in Table 5.

\subsection{The Level of Competitive Anxiety}

Mean scores and standard deviations for the different dimensions of precompetitive anxiety are shown in Table 6.

Generally, self-confidence is indicated as the most identified dimension in our participants, it is interpreted as a facilitator of performance and constantly demanded over time.

In relation to the training center factor, the dimension of self-confidence is most accepted by our elites across all three scales (see Table 7).

The same results are revealed in both levels of experience, and in relation to the different positions of each young talent (see Table 8 and Table 9). 
Table 4. Factor loads.

\begin{tabular}{|c|c|c|c|c|c|c|c|c|c|c|c|}
\hline \multicolumn{4}{|c|}{ Scale of intensity } & \multicolumn{4}{|c|}{ Scale of direction } & \multicolumn{4}{|c|}{ Scale of frequency } \\
\hline & 1 & 2 & 3 & & 1 & 2 & 3 & & 1 & 2 & 3 \\
\hline i15 & 0.898 & & & D6 & 0.851 & & & $\mathrm{~F} 15$ & 0.838 & & \\
\hline $\mathrm{i} 12$ & 0.884 & & & D9 & 0.782 & & & $\mathrm{~F} 12$ & 0.837 & & \\
\hline i6 & 0.872 & & & $\mathrm{D} 4$ & 0.777 & 0.323 & & $\mathrm{~F} 4$ & 0.822 & & \\
\hline i9 & 0.826 & & & D12 & 0.738 & 0.344 & & F6 & 0.800 & & \\
\hline i17 & 0.764 & & & D15 & 0.728 & & & F9 & 0.790 & 0.348 & \\
\hline i4 & 0.702 & & & D17 & 0.716 & & & F17 & 0.737 & & \\
\hline $\mathrm{i} 10$ & & 0.910 & & D8 & & 0.809 & & $\mathrm{~F} 2$ & & 0.861 & \\
\hline i7 & & 0.891 & & D11 & & 0.799 & & $\mathrm{~F} 14$ & & 0.792 & \\
\hline i13 & & 0.814 & & D14 & 0.326 & 0.723 & & F5 & & 0.705 & \\
\hline i3 & & 0.787 & & D2 & 0.339 & 0.687 & & F8 & & 0.692 & \\
\hline i16 & & 0.718 & & D5 & & 0.667 & & F11 & 0.368 & 0.687 & \\
\hline i14 & & & 0.770 & D10 & & & 0.875 & $\mathrm{~F} 13$ & & & 0.833 \\
\hline i11 & & & 0.732 & D3 & & & 0.807 & F10 & -0.338 & & 0.788 \\
\hline i2 & & & 0.708 & D7 & & & 0.790 & F7 & & & 0.743 \\
\hline i5 & & & 0.706 & D13 & & & 0.751 & F3 & & & 0.721 \\
\hline i8 & & & 0.692 & D16 & & & 0.650 & F16 & & & 0.624 \\
\hline
\end{tabular}

Table 5. Adjustment indices.

\begin{tabular}{cccccccc}
\hline & $\mathrm{X} 2$ & $\mathrm{X} 2 / \mathrm{df}$ & $\mathrm{Df}$ & $\mathrm{P}$ & $\mathrm{CFI}$ & $\mathrm{TLI}$ & RMSEA \\
\hline intensity scale & 134.939 & 1.336 & 101 & 0.014 & 0.947 & 0.937 & 0.067 \\
direction scale & 129.349 & 1.281 & 101 & 0.030 & 0.952 & 0.944 & 0.061 \\
frequency scale & 147.079 & 1.456 & 101 & 0.002 & 0.925 & 0.911 & 0.078 \\
\hline
\end{tabular}

Table 6. Precompetitive anxiety scores.

\begin{tabular}{cccccccccc}
\hline & ICA & ISA & ISC & DCA & DSA & DSC & FCA & FSA & FSC \\
\hline Means & 10.96 & 12.21 & 16.51 & -2.89 & -4.54 & 8.37 & 15.20 & 14.17 & 28.29 \\
SD & 3.67 & 5.05 & 3.76 & 7.50 & 8.16 & 6.46 & 7.04 & 6.89 & 5.63 \\
$\mathrm{~N}$ & 76 & 76 & 76 & 76 & 76 & 76 & 76 & 76 & 76
\end{tabular}

Intensity of cognitive anxiety: Direction of cognitive anxiety: Frequency of cognitive anxiety:

\begin{tabular}{ccc} 
ICA & DCA & FCA \\
\hline Intensity of somatic anxiety: & Direction of somatic anxiety: & Frequency of somatic anxiety: \\
ISA & DAS & FAS \\
\hline Intensity of self-confidence: & Direction of self-confidence: & Frequency of self-confidence: \\
ISC & DSC & FSC \\
\hline
\end{tabular}

\subsection{The Effects of Interactions}

Through MANOVA variance analysis, we distinguished only the effect of coaching on pre-competitive anxiety perceived by our participants

[Wilks Lambda $=0.292<1, \mathrm{~F}=2.050, P=0.005<0.05$ ] (see Table 10) 
Table 7. Pre-competitive anxiety scores versus training centers.

\begin{tabular}{ccccccccccc}
\hline \multicolumn{2}{c}{ Training centers } & ICA & ISA & ISC & DCA & DSA & DSC & FCA & FSA & FSC \\
\hline \multirow{2}{*}{ GAFSA } & Means & 11.75 & 11.25 & 16.50 & -3.90 & -5.05 & 6.15 & 16.10 & 15.05 & 26.20 \\
& SD & 4.42 & 5.02 & 2.06 & 7.43 & 5.94 & 7.58 & 7.86 & 6.24 & 6.58 \\
& $\mathrm{~N}$ & 20 & 20 & 20 & 20 & 20 & 20 & 20 & 20 & 20 \\
SIDI & Means & 10.89 & 13.52 & 14.42 & -2.47 & -3.16 & 7.89 & 16.95 & 16.26 & 27.16 \\
BOUZI & SD & 3.75 & 5.31 & 5.05 & 9.80 & 10.88 & 7.89 & 7.83 & 7.68 & 6.33 \\
D & $\mathrm{N}$ & 19 & 19 & 19 & 19 & 19 & 19 & 19 & 19 & 19 \\
& $\mathrm{Neans}$ & 9.80 & 12.20 & 17.30 & -2.40 & -3.30 & 9.55 & 11.85 & 9.90 & 30.25 \\
GABES & $\mathrm{SD}$ & 2.89 & 5.00 & 3.64 & 6.19 & 8.22 & 5.08 & 5.08 & 3.51 & 4.62 \\
& $\mathrm{~N}$ & 20 & 20 & 20 & 20 & 20 & 20 & 20 & 20 & 20 \\
& Means & 11.47 & 11.88 & 17.94 & -2.76 & -6.94 & 10.12 & 16.11 & 15.82 & 29.70 \\
LE KEF & $\mathrm{SD}$ & 3.39 & 4.97 & 2.92 & 6.52 & 6.82 & 3.88 & 6.30 & 7.96 & 3.58 \\
& $\mathrm{~N}$ & 17 & 17 & 17 & 17 & 17 & 17 & 17 & 17 & 17 \\
\hline
\end{tabular}

Table 8. Precompetitive anxiety scores in relation to the level of experience.

\begin{tabular}{ccccccccccc}
\hline \multicolumn{2}{c}{ Experience Level } & ICA & ISA & ISC & DCA & DSA & DSC & FCA & FSA & FSC \\
\hline \multirow{2}{*}{$\begin{array}{c}\text { Below 2 } \\
\text { years }\end{array}$} & Means & 10.92 & 12.11 & 16.19 & -2.80 & -4.41 & 8.65 & 15.69 & 14.69 & 27.54 \\
& $\mathrm{~N}$ & 3.33 & 5.32 & 3.73 & 7.87 & 7.82 & 6.08 & 7.42 & 7.57 & 6.43 \\
& Means & 10.98 & 12.26 & 16.68 & -2.94 & -4.58 & 8.22 & 14.94 & 13.90 & 28.68 \\
over 2 & $\mathrm{SD}$ & 3.87 & 4.95 & 3.80 & 7.37 & 8.41 & 6.70 & 6.90 & 6.57 & 5.19 \\
years & $\mathrm{N}$ & 50 & 50 & 50 & 50 & 50 & 50 & 50 & 50 & 50 \\
\hline
\end{tabular}

Table 9. Pre-competitive anxiety scores in relation to the player's position.

\begin{tabular}{|c|c|c|c|c|c|c|c|c|c|c|}
\hline \multicolumn{2}{|c|}{ technical position } & \multirow{2}{*}{$\begin{array}{c}\mathrm{ICA} \\
12.20\end{array}$} & \multirow{2}{*}{$\begin{array}{c}\text { ISA } \\
14.00\end{array}$} & \multirow{2}{*}{$\begin{array}{c}\text { ISC } \\
16.10\end{array}$} & \multirow{2}{*}{$\begin{array}{c}\text { DCA } \\
-1.80\end{array}$} & \multirow{2}{*}{$\begin{array}{c}\text { DSA } \\
-2.10\end{array}$} & \multirow{2}{*}{$\begin{array}{c}\text { DSC } \\
6.80\end{array}$} & \multirow{2}{*}{$\begin{array}{c}\text { FCA } \\
13.90\end{array}$} & \multirow{2}{*}{$\begin{array}{c}\text { FSA } \\
18.60\end{array}$} & \multirow{2}{*}{$\begin{array}{l}\text { FSC } \\
27.30\end{array}$} \\
\hline & Means & & & & & & & & & \\
\hline \multirow[t]{3}{*}{ Goalkeeper } & SD & 2.57 & 5.83 & 3.28 & 8.19 & 9.16 & 6.96 & 7.23 & 8.63 & 6.00 \\
\hline & $\mathrm{N}$ & 10 & 10 & 10 & 10 & 10 & 10 & 10 & 10 & 10 \\
\hline & Means & 10.18 & 13.63 & 16.27 & -4.23 & -5.09 & 8.91 & 16.23 & 14.50 & 27.18 \\
\hline \multirow{3}{*}{$\begin{array}{c}\text { Defender } \\
\text { player }\end{array}$} & $\mathrm{SD}$ & 4.17 & 4.98 & 4.44 & 6.92 & 8.09 & 7.35 & 9.02 & 7.02 & 6.41 \\
\hline & $\mathrm{N}$ & 22 & 22 & 22 & 22 & 22 & 22 & 22 & 22 & 22 \\
\hline & Means & 11.00 & 10.62 & 17.71 & -1.86 & -5.52 & 8.24 & 15.24 & 13.66 & 29.05 \\
\hline \multirow{3}{*}{$\begin{array}{l}\text { Midfield } \\
\text { player }\end{array}$} & $\mathrm{SD}$ & 3.75 & 4.62 & 2.95 & 7.63 & 8.82 & 6.63 & 6.95 & 6.76 & 5.58 \\
\hline & $\mathrm{N}$ & 21 & 21 & 21 & 21 & 21 & 21 & 21 & 21 & 21 \\
\hline & Means & 11.13 & 11.52 & 15.83 & -3.04 & -4.17 & 8.65 & 14.74 & 12.39 & 29.09 \\
\hline \multirow[t]{2}{*}{$\begin{array}{l}\text { Attack } \\
\text { player }\end{array}$} & $\mathrm{SD}$ & 3.54 & 4.85 & 3.87 & 7.89 & 7.45 & 5.41 & 4.89 & 5.49 & 4.79 \\
\hline & $\mathrm{N}$ & 23 & 23 & 23 & 23 & 23 & 23 & 23 & 23 & 23 \\
\hline
\end{tabular}


Table 10. Impact of coaching, experience and technical position on precompetitive anxiety.

\begin{tabular}{ccccccc}
\hline \multirow{2}{*}{ Effect } & Value & F & ddl of the hypothesis & Error ddl & Significance \\
\hline \multirow{4}{*}{ Coaching } & Trace of Pillai & 0.976 & 2.036 & 27.000 & 114.000 & 0.005 \\
& Wilks Lambda & 0.292 & 2.050 & 27.000 & 105.781 & 0.005 \\
& Hotelling Trace & 1.600 & 2.054 & 27.000 & 104.000 & 0.005 \\
& Largest Roy Root & 0.951 & $4.014 \mathrm{c}$ & 9.000 & 38.000 & 0.001 \\
& Trace of Pillai & 0.134 & $0.619 \mathrm{~b}$ & 9.000 & 36.000 & 0.772 \\
$\begin{array}{c}\text { Experience } \\
\text { level }\end{array}$ & Wilks Lambda & 0.866 & $0.619 \mathrm{~b}$ & 9.000 & 36.000 & 0.772 \\
& Hotelling Trace & 0.155 & $0.619 \mathrm{~b}$ & 9.000 & 36.000 & 0.772 \\
& Largest Roy Root & 0.155 & $0.619 \mathrm{~b}$ & 9.000 & 36.000 & 0.772 \\
\multirow{2}{*}{$\begin{array}{c}\text { Technical } \\
\text { post }\end{array}$} & Trace of Pillai & 0.605 & 1.066 & 27.000 & 114.000 & 0.393 \\
& Wilks Lambda & 0.501 & 1.045 & 27.000 & 105.781 & 0.419 \\
& Hotelling Trace & 0.796 & 1.022 & 27.000 & 104.000 & 0.448 \\
& Largest Roy Root & 0.434 & $1.834 \mathrm{c}$ & 9.000 & 38.000 & 0.094 \\
\hline
\end{tabular}

b. Exact statistics; $\mathrm{c}$. The statistic is an upper bound of $\mathrm{F}$ that produces a lower bound on the level of significance.

The dimensions affected by this effect are the intensity of self-confidence and the frequency of somatic anxiety (see Table 11).

\section{Discussion}

\subsection{The Psychometric Properties of the Measuring Instrument}

\subsubsection{The Internal Consistency of the Scale}

The coefficients of a Cronbach, are approved, and similar to those of the French version of Martinent et al. (2010). In general, a Cronbach coefficients vary between 0.734 and 0.912, which are acceptable (De Vellis, 1991).

\subsubsection{Exploratory Factor Analysis for the Three Scales}

\section{1) The Kaiser-Meyer-Olkin Index}

The value of Kaiser-Meyer-Olkin, which gives a global idea about the quality of inter-item correlations, is always greater than 0.5 .

The KMO value for the scale of intensity equal to 0.801 , for the scale of the direction equals 0.839 , and for the scale of the frequency equal to 0.806 , demonstrate that the correlations between the items are of good quality.

\section{2) Bartlett Sphericity Test}

The result of Bartlett's sphericity test for intensity, direction and frequency scales is still significant at $p<0.05$. We can therefore reject the null hypothesis that our data come from a population for which the matrix is an identity matrix, so the correlations are not all equal to zero.

\section{3) Determinant of the matrix}

The determinant values of the matrix for the three CSAI-2R scales are always small but different at zero (the intensity scale determinant $=4.149 \mathrm{E}-5$, the 
Table 11. Inter-subject effects tests.

\begin{tabular}{cccccc}
\hline \multirow{2}{*}{ Source } & Dependent variable & $\begin{array}{c}\text { Sum of type III } \\
\text { squares }\end{array}$ & Middle square & F & Significance \\
\cline { 3 - 5 } & Intensity of Cognitive anxiety & 78.713 & 26.238 & 2.097 & 0.114 \\
& Intensity of Somatic anxiety & 43.479 & 14.493 & 0.575 & 0.635 \\
& Intensity of Self-confidence & 179.053 & 59.684 & 4.482 & 0.008 \\
& Direction of Scale of intensity & 121.400 & 40.467 & 0.585 & 0.628 \\
Coaching & Direction of Cognitive anxiety & 312.310 & 104.103 & 1.607 & 0.201 \\
& Direction of Somatic anxiety & 159.612 & 53.204 & 1.044 & 0.383 \\
& Frequency of Self-confidence & 310.142 & 103.381 & 2.387 & 0.082 \\
& Frequency of Scale of direction & 758.911 & 252.970 & 10.345 & 0.000 \\
Frequency of Cognitive anxiety & 221.251 & 73.750 & 2.018 & 0.125 \\
\hline
\end{tabular}

direction scale determinant $=7.118 \mathrm{E}-5$ and the determinant of the frequency scale $=5.701 \mathrm{E}-5$ ), confirming the absence of multicollinearity (Hair et al., 2010).

\subsubsection{Confirmatory Factor Analysis}

According to Tabachnick \& Fidell (2007), the results of the confirmatory factor analysis showed good fit indices for the three scales of our measuring instrument.

- The intensity scale: $[\mathrm{X} 2=134.94$ at $\mathrm{p}=0.014$; $\mathrm{CFI}=0.947$; $\mathrm{TLI}=0.937$ and RMSEA $=0.067$,

- The scale of the direction: $[\mathrm{X} 2=129.35$ at $\mathrm{p}=0.030$; $\mathrm{CFI}=0.952$; $\mathrm{TLI}=0.944$ and RMSEA $=0.061$,

- The frequency scale: [X2 $=147.08$ at $\mathrm{p}=0.002$; $\mathrm{CFI}=0.925 ; \mathrm{TLI}=0.911$ and RMSEA $=0.078]$.

The AMOS software (see Figures 1-3), validates the factor structure of the three scales of the Tunisian version of CSAI-2R, which we used in our study.

\subsection{The Level of Precompetitive Anxiety}

According to the scores of the different dimensions of precompetitive anxiety, the dimension of self-confidence through its three measures, is the most identified among our young talents.

The same results were confirmed in relation to the factors of coaching, experience and technical position (defender, striker, goalkeeper...).

In this context, several studies confirm that elite athletes bring lower levels of cognitive and somatic anxiety intensity, and higher levels of precompetitive self-confidence.

These results are similar to those published in the work of Wolfram et al. (2008: pp. 153-159), among elite riders evaluated by CSAI-2R.

Similar results have been confirmed in elite gymnasts and swimmers (Jones et al., 1994: pp. 657-663), elite tennis players (Perry \& Williams, 1998: pp. 169-179), 


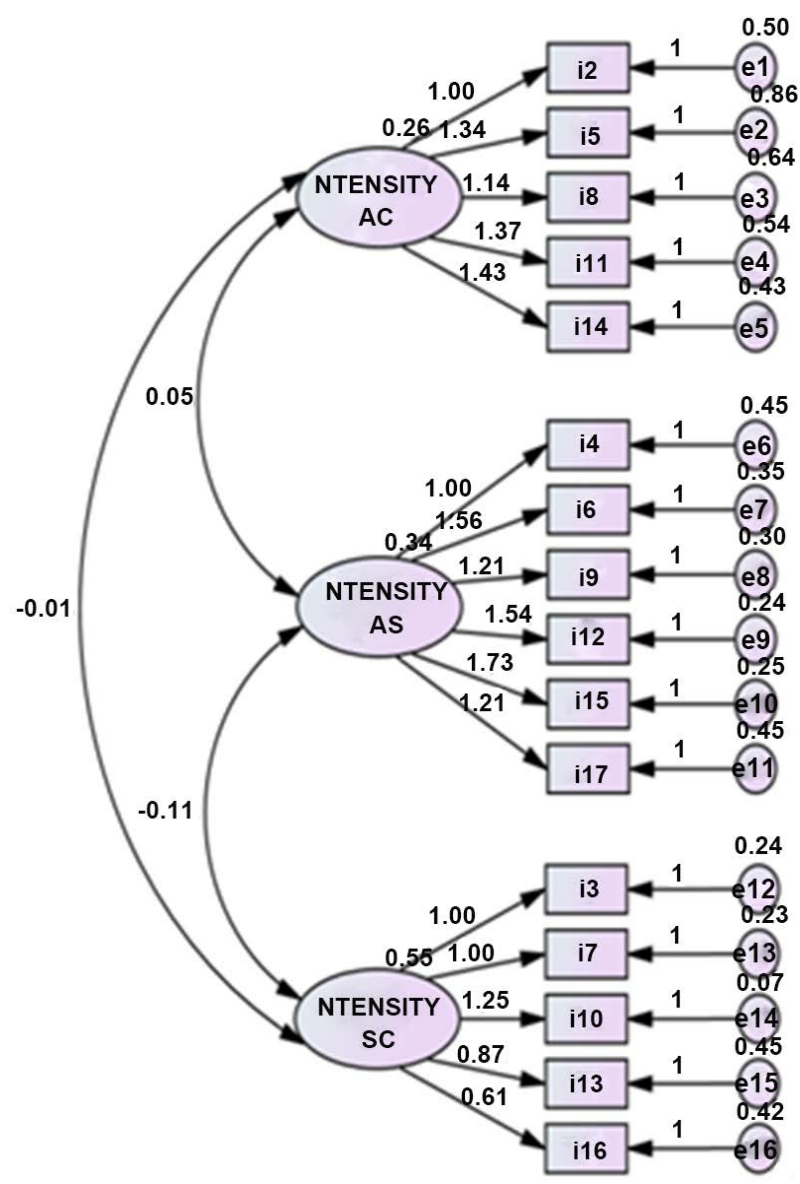

Figure 1. Model of the hypothetical structure: the intensity scale. Circles represent latent constructions and squares represent measured variables. All parameters are standardized and significant at $\mathrm{p}<0.05$. Residual differences are indicated in small circles.

elite wrestlers (Highlen \& Bennett, 1979: pp. 123-137), and elite gymnasts (Mahoney \& Avener, 1977).

In the works of Hanton et al. (2004: pp. 169-181), and Jones \& Swain (1995: pp. 201-211), elite athletes brought high levels of direction to precompetitive anxiety.

In the same vein, Mellalieu et al. (2006), reported high levels of the direction of precompetitive anxiety and the intensity of precompetitive self-confidence in elite athletes.

Hanton \& Jones (1999: pp. 1-21), also reported that the majority of elite swimmers (85.3\%) presented facilitative perceptions of pre-competitive anxiety. In addition, Hanton et al. (2004: pp. 169-181), Craft et al. (2003: pp. 44-65), Hanton et al. (2002: pp. 911-928), indicate that measures of the intensity and frequency of pre-competitive anxiety manifest themselves as, predictors less important than the measure of direction, in elite athletes.

On the other hand, and in relation to the level of experience, Rokka et al. (2009: pp. 178-153), confirmed that with 4 to 6 years of experience, the athlete 


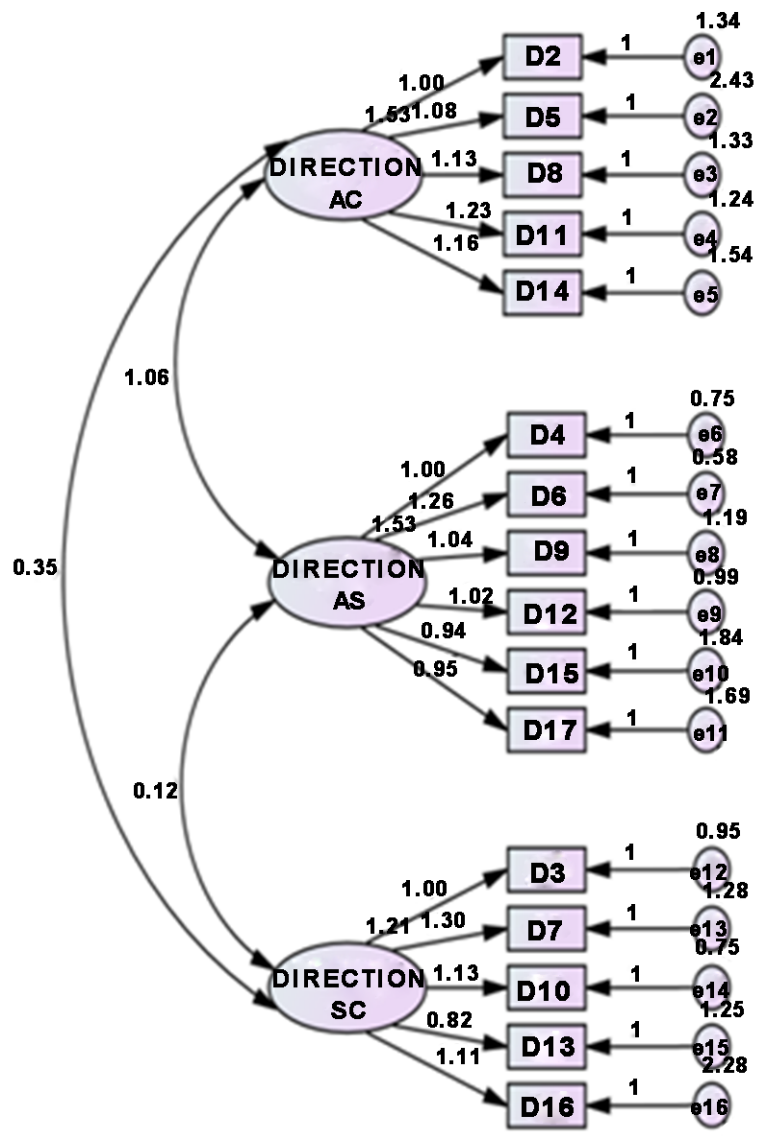

Figure 2. Model of the hypothetical structure: the direction scale. Circles represent latent constructions and squares represent measured variables. All parameters are standardized and significant at $\mathrm{p}<0.05$. Residual differences are indicated in small circles.

can adopt high levels of precompetitive self-confidence intensity and a facilitative directional interpretation of precompetitive anxiety. In contrast, less experienced athletes have revealed lower levels of self-confidence, with effects that are neither facilitative nor debilitating on their performance.

In contrast, Singley et al. (2012: pp. 453-496), recently reported that there are no significant differences in frequency and direction levels of precompetitive cognitive and somatic anxiety, and in the level of intensity of precompetitive self-confidence between expert and non-expert cavaliers.

Based on the results obtained in our study and the results presented above, we have noted that most studies indicate that expert athletes reveal low levels of cognitive and somatic anxiety intensity and high levels of anxiety. Self-confidence with facilitating directional interpretations and positive diffusion over time of precompetitive anxiety.

Compared to the "technical station" factor, our study shows that through the three measures of pre-competitive anxiety, self-confidence is the most sought-after dimension by goalkeepers, defenders, players in the middle and 


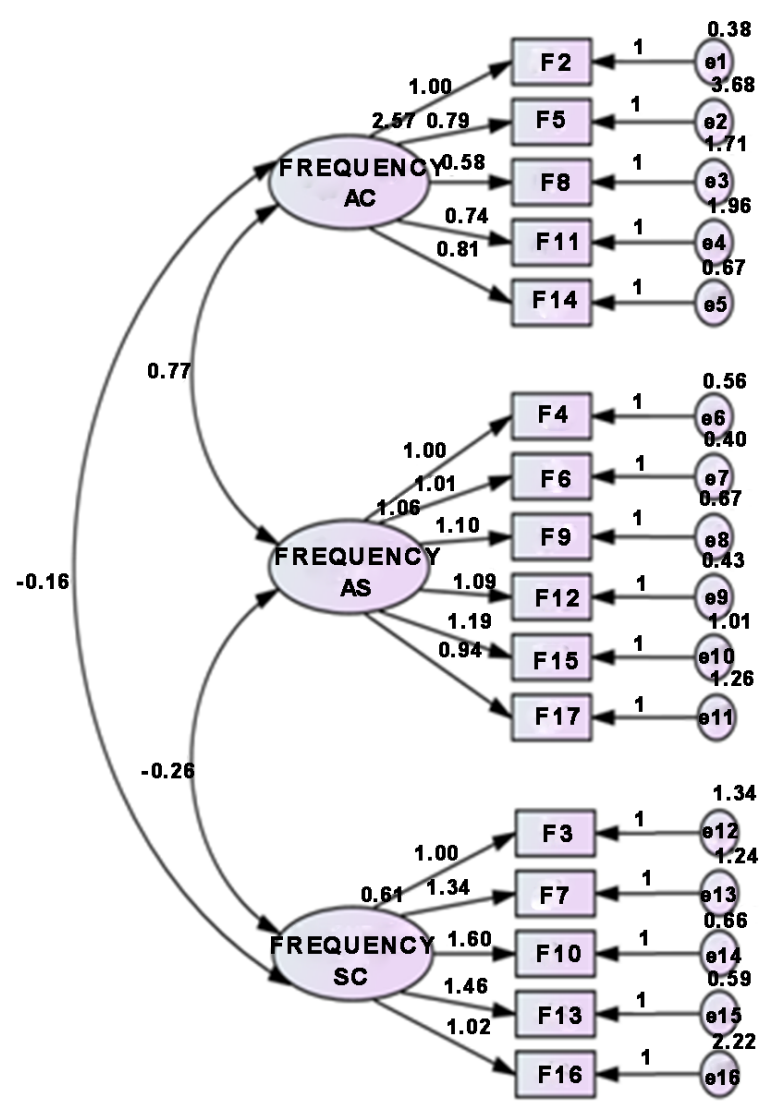

Figure 3. Model of the hypothetical structure: the frequency scale. Circles represent latent constructions and squares represent measured variables. All parameters are standardized and significant at $\mathrm{p}<0.05$. Residual differences are indicated in small circles.

attackers. In this context and following a thorough analysis of literature reviews in sports psychology, we found that our study is innovative in this field of study.

\subsection{The Effects of Interactions}

MANOVA variance analysis, which we performed to estimate interaction effect, coaching, experience and technical position, only demonstrates the presence of coaching influence on precompetitive anxiety in our participants.

The research interest in coaching behaviors and its effects on psychological variables such as anxiety (Keegan et al., 2011: pp. 1-55), is exploited in young athletes with competitive practice (Fry et al., 2010: pp. 294-304; Gould et al., 2012: pp. 80-87).

According to Martin et al. (2014: pp. 111-123), young Americans view coaches as positive ascendants positive about their behaviors. In the same context, Balaguer et al. (2007: pp. 123-139), ask that the coach support a favorable psychological environment for young athletes to exploit their maximum potential during the competition.

The coach-trainer represents informational support (Wolfenden \& Holt, 2005: 
pp. 108-126), and emotional support (Reinboth et al., 2004: pp. 297-313). Coaches are among the most influential social factors in young athletes (Brustad et al., 2001: pp. 604-635).

It has been justified that the motivational climate established by the coach (Gould et al., 2012: pp. 80-87; Smith et al., 2006: pp. 479-501) and the acts that he has commits to circulate (Fry et al., 2010: pp. 294-304), have a direct influence on the personal and social development of young athletes.

In addition, coaches can have a negative influence on athletes (Keegan et al., 2011: pp. 1-55), through certain behaviors which disadvantage the development of athletes (Reinboth \& Duda, 2006: pp. 269-286).

\section{Conclusion}

The management of stress and more precisely pre-competitive anxiety is a fundamental objective for the athlete and for all the actors active in the institutional system of training.

In this context, our work has been designed to present a well detailed repertoire to understand how pre-competitive anxiety is identified in our young footballers, during the main competitive events.

In our elite U15 footballers, the directional interpretation of self-confidence is always favorable for performance, and positively continuous over time.

The MANOVA analysis only shows the impact of the coach trainer. But the regression analysis did not reveal any significant predictive linear relationships.

On the other hand, the study of pre-competitive anxiety in relation to the technical position, such as the goalkeeper, the defender, the middle player or the attacker, is considered the first in this field of study.

Among the limitations of our work, we had examined only pre-competitive state anxiety and neglected precompetitive anxiety trait. However, the effect of personality, for example, among young elites in a decisive pre-training phase seems important to us for a highly selective career.

\section{References}

Balaguer, I., Castillo, I., \& Duda, J. L. (2007). Soutien à l'autonomie, la satisfaction des besoins, la motivation et le bien-être chez les athlètes de compétition: Une analyse de la théorie de l'autodétermination. Revista de Psicología del Deporte, 17, 123-139.

Brustad, R. J., Babkes, M. L., \& Smith, A. L. (2001). Youth in Sport: Psychological Considerations. Handbook of Sport Psychology, 2, 604-635.

Craft, L. L., Magyar, T. M., Becker, B. J., \& Feltz, D. L. (2003). The Relationship between the Competitive State Anxiety Inventory-2 and Sport Performance: A Meta-Analysis. Journal of Sport \& Exercise Psychology, 25, 44-65. https://doi.org/10.1123/jsep.25.1.44

DeVellis, R. F. (1991). Scale Development: Theory and Applications (pp. 27-60). Newbury Park: Sage Publications, Inc.

Fry, M. D., \& Gano-Overway, L. A. (2010). Exploring the Contribution of the Caring Climate to the Youth Sport Experience. Journal of Applied Sport Psychology, 22, 294-304. https://doi.org/10.1080/10413201003776352

Gould, D., Flett, R., \& Lauer, L. (2012). The Relationship between Psychosocial Develop- 
mental and the Sports Climate Experienced by Underserved Youth. Psychology of Sport and Exercise, 13, 80-87. https://doi.org/10.1016/j.psychsport.2011.07.005

Grossbard, J. R., Smith, R. E., Smoll, F. L., \& Cumming, S. P. (2009). Competitive Anxiety in Young Athletes: Differentiating Somatic Anxiety, Worry, and Concentration Disruption. Anxiety, Stress, \& Coping, 22, 153-166. https://doi.org/10.1080/10615800802020643

Hair, J. F., Black, W. C., Babin, B. J., Anderson, R. E., \& Tatham, R. L. (2010). Multivariate Data Analysis (7th ed., pp. 91-234). Englewood Cliffs: Prentice Hall.

Hajji, J., \& Elloumi, A. (2017). Validation of the Tunisian Version of the French Version of the Competitive State Anxiety Inventory-2 Revised (CSAI-2R), Including Frequency and Direction Scales. International Journal of Emergency Mental Health, 19, 1-7. https://doi.org/10.4172/1522-4821.1000363

Hanton, S., \& Jones, G. (1999). The Acquisition and Development of Cognitive Skills and Strategies: I. Making the Butterflies Fly in Formation. The Sport Psychologist, 13, 1-21. https://doi.org/10.1123/tsp.13.1.1

Hanton, S., Mellalieu, S. D., \& Young, S. G. (2002). A Qualitative Investigation into the Temporal Patterning of the Precompetitive Anxiety Response. Journal of Sports Sciences, 20, 911-928. https://doi.org/10.1080/026404102320761804

Hanton, S., Thomas, O., \& Maynard, I. (2004). Competitive Anxiety Responses in the Week Leading up to Competition: The Role of Intensity, Direction and Frequency Dimensions. Psychology of Sport and Exercise, 5, 169-181. https://doi.org/10.1016/S1469-0292(02)00042-0

Hardy, L. (1999). Stress, Anxiety and Performance. Journal of Science and Medicine in Sport, 2, 227-233. https://doi.org/10.1016/S1440-2440(99)80175-3

Highlen, P. S., \& Bennett, B. B. (1979). Psychological Characteristics of Successful and Nonsuccessful Elite Wrestlers: An Exploratory Study. Journal of Sport-Psychology, 1, 123-137. https://doi.org/10.1123/jsp.1.2.123

Horikawa, M., \& Yagi, A. (2012). The Relationships among Trait Anxiety, State Anxiety and the Goal Performance of Penalty Shoot-Out by University Soccer Players. Plos One 7, e35727. https://doi.org/10.1371/journal.pone.0035727

Jones, G., \& Swain, A. (1995). Predispositions to Experience Debilitative and Facilitative Anxiety in Elite and Non-Elite Performers. The Sport Psychologist, 9, 201-211. https://doi.org/10.1123/tsp.9.2.201

Jones, G., Hanton, S., \& Swain, A. (1994). Intensity and Interpretation of Anxiety Symptoms in Elite and Non Elite Sports Performers. Personality and Individual Differences, 17, 657-663. https://doi.org/10.1016/0191-8869(94)90138-4

Keegan, R., Spray, C., Harwood, C., \& Lavallee, D. (2011). From "Motivational Climate" to "Motivational Atmosphere": A Review of Research Examining the Social and Environmental Influences on Athlete Motivation in Sport (pp. 1-55).

Khodayari, B., Saiiari, A., \& Dehghani, Y. (2011). Comparison Relation between Mental Skills with Sport Anxiety in Sprint and Endurance Runners. Procedia-Social and Behavioral Sciences, 30, 2280-2284. https://doi.org/10.1016/j.sbspro.2011.10.445

Lazarus, R. S. (2000). How Emotions Influence Performance in Competitive Sports. The Sport Psychologist, 14, 229-252. https://doi.org/10.1123/tsp.14.3.229

Lazarus, R. S., \& Folkman, S. (1984a). Coping and Adaptation. In W. D. Gentry (Ed.), Handbook of Behavior Medicine (pp. 141-325). New York, NY: Guilford.

Lazarus, R. S., \& Folkman, S. (1984b). Stress, Appraisal, and Coping (pp. 283-284). New York, NY: Springer. 
Mahoney, M. J., \& Avener, M. (1977). Psychology of the Elite Athlete: An Exploratory Study. Cognitive Therapy and Research, 1, 135-141.

https://doi.org/10.1007/BF01173634

Martin, E. M., Ewing, M. E., \& Gould, D. (2014). Social Agents' Influence on Self-Perceived Good and Bad Behavior of American Youth Involved in Sport: Developmental Level, Gender, and Competitive Level Effects. The Sport Psychologist, 28, 111-123. https://doi.org/10.1123/tsp.2013-0005

Martinent, G., Ferrand, C., Guillet, E., \& Gautheur, S. (2010). Validation of the French Version of the Competitive State Anxiety Inventory-2 Revised (CSAI-2R) Including Frequency and Direction Scales. Psychology of Sport and Exercise, 11, 51-57. https://doi.org/10.1016/j.psychsport.2009.05.001

Mellalieu, S. D., Neil, R., \& Hanton, S. (2006). An Investigation of the Mediating Effects of Self-Confidence between Anxiety Intensity and Direction. Research Quarterly for Sport and Exercise, 77, 263-270. https://doi.org/10.1080/02701367.2006.10599359

Perry, J. D., \& Williams, J. M. (1998). Relationship of Intensity and Direction of Competitive Trait Anxiety to Skill Level and Gender in Tennis. The Sport Psychologist, 12, 169-179. https://doi.org/10.1123/tsp.12.2.169

Reinboth, M., \& Duda, J. L. (2006). Perceived Motivational Climate, Need Satisfaction and Indices of Well-Being in Team Sports: A Longitudinal Perspective. Psychology of Sport and Exercise, 7, 269-286. https://doi.org/10.1016/j.psychsport.2005.06.002

Reinboth, M., Duda, J. L., \& Ntoumanis, N. (2004). Dimensions of Coaching Behavior Need Satisfaction, and the Psychological and Physical Welfare of Young Athletes. Motivation and Emotion, 28, 297-313. https://doi.org/10.1023/B:MOEM.0000040156.81924.b8

Rokka, S., Mavridis, G., Bebetsos, E., \& Mavridis, K. (2009). Competitive State Anxiety among Junior Handball Players. Scandinavian Journal of Medicine and Science in Sport, 42, 148-153.

Sangari, M., Fotrousi, F., \& Masrour, F. F. (2012). Relationship between Mental Skill and Competitive Anxiety in Female National Football Players. World Applied Sciences Journal, 20, 1175-1178.

Singley, K. I., Hale, B. D., \& Russell, D. M. (2012). Heart Rate, Anxiety, and Hardiness in Novice (Tandem) and Experienced (Solo) Skydivers. Journal of Sport Behavior, 35, 453-496.

Skinner, N., \& Brewer, N. (2002). The Dynamics of Threat and Challenge Appraisals Prior to Stressful Achievements Events. Journal of Personality and Social Psychology, 83, 678-692. http://psycnet.apa.org/doi/10.1037/0022-3514.83.3.678

Smith, R. E., Smoll, F. L., Cumming, S. P., \& Grossbard, J. R. (2006). Measurement of Multidimensional Sport Performance Anxiety in Children and Adults: The Sport Anxiety Scale-2. Journal of Sport and Exercise Psychology, 28, 479-501. https://doi.org/10.1123/jsep.28.4.479

Stavrou, N. A., Psychountaki, M., \& Zervas, Y. (2006). Intensity and Direction Dimensions of Competitive State Anxiety: A Time-to-Event Approach. Perceptual and Motor Skills, 103, 91-98.

Tabachnick, B. G., \& Fidell, L. S. (2007). Using Multivariate Statistics (5th ed.). Boston, MT: Pearson Education.

Wolfenden, L. E., \& Holt, N. L. (2005). Talent Development in Elite Junior Tennis: Perceptions of Players, Parents, and Coaches. Journal of Applied Sport Psychology, 17, 108-126. https://doi.org/10.1080/10413200590932416 
Wolfram, I. A., \& Micklewright, D. (2008). Pre-Competitive Levels of Arousal and Self-Confidence among Elite and Non-Elite Equestrian Riders. Comparative Exercise Physiology, 5, 153-159.

Woodman, T., \& Hardy, L. (2003). The Relative Impact of Cognitive Anxiety and Self-Confidence upon Sport Performance: A Meta-Analysis. Journal of Sports Sciences, 21, 443-457. https://doi.org/10.1080/0264041031000101809 